\title{
STUDI ADSORPSI TIMBAL PADA MEMBRAN KITOSAN TERMODIFIKASI POLIDOPAMIN
}

\author{
Chairunnisa,* \\ ${ }^{1}$ Jurusan Sains, Institut Teknologi Sumatera, Jl. Terusan Ryacudu, Way Hui, Lampung Selatan, 35365, \\ Indonesia \\ * Author Utama, email: chairun.nisa@ki.itera.ac.id
}

\begin{abstract}
Polyethylene glycol (PEG) and polydopamine (PDA) modified chitosan membranes has been conducted. There are differences between modified and unmodified membranes physically. The adsorption capacity of membranes before and after modified was analyzed by batch adsorption method. The target of the adsorption study was $\mathrm{Pb}$ (II) ion. The maximum adsorption capacity was owned by chitosan membrane modified by $10 \%$ peg dan $1 \mathrm{~kg} / \mathrm{L}$ pda. The $\% R$ of this membrane was $54 \%$.
\end{abstract}

Keywords: membrane; chitosan; polyethylene glycol, polydopamine

\section{ABSTRAK}

Membran kitosan termodifikasi polietilen glikol (PEG) dan polidopamin (PDA) telah dibuat dengan metoda pelapisan (coating). Terdapat perbedaan fisik dari membran sebelum dan sesudah modifikasi. Kapasitas adsorpsi membran kitosan sebelum dan sesudah modifikasi telah dianalisis dengan menggunakan larutan yang mengandung ion $\mathrm{Pb}$ (II) sebagai target polutan. Kapasitas adsorpsi tertinggi diperoleh oleh membran kitosan termodifikasi $10 \%$ peg dan pda sebanyak $1 \mathrm{~kg} / \mathrm{L}$ dengan besar $\% R$ yaitu $54 \%$.

Kata Kunci: membran;kitosan;polietilen glikol ; polidopamin

\section{PENDAHULUAN}

Air merupakan pendukung utama dalam kehidupan. Kemajuan indutri modern memiliki dampak langsung terhadap ketersediaan air bersih. Hasil buangan dari industri-industri mengandung zat-zat yang mencemari sumber air. Air yang tercemar akan mempengaruhi kualitas hidup. Salah satu pencemar yang banyak terdapat di dalam air adalah logam berat. Keberadaan logam berat berdampak negatif bagi kesehatan makhluk hidup. Sehingga, sangatlah penting untuk mengurangi bahkan menghilangkan kadar logam berat yang terkandung dalam air. Beberapa metode yang digunakan dalam hal tersebut antara lain metoda penukar ion, adsorpsi, pengendapan dan koagulasi.
Diantara beberapa metode tersebut, metoda adsorpsi dipilih karena memilliki beberapa kelebihan yaitu mudah dan murah untuk diaplikasikan [1].

Salah satu adsorben yang banyak dikembangkan adalah membran. Membran dikembangkan karena keunggulannya yaitu memiliki luas permukaan, porositas dan jumlah gugus aktif yang besar, sehingga baik digunakan dalam aplikasi adsorpsi [2]. Selain sifat-sifat tersebut, salah satu hal yang perlu dikembangkan adalah membran dari material yang ramah lingkungan. Kitosan adalah salah satu material alam yang non toksik, mudah terdegradasi dan melimpah [3]. Kitosan juga memiliki banyak gugus hidroksil dan amina yang efektif dalam mengikat logam berat [4]. 
Dalam rangka menghasilkan material dengan kapasitas adsorpsi yang tinggi, adsorben sebaiknya memiliki jumlah gugus aktif yang melimpah sehingga interaksi antara adsorben dengan adsorbat semakin banyak. Oleh sebab itu, digunakan beberapa polimer dalam memodifikasi membran kitosan untuk memperkaya jumlah dan jenis gugus aktif material tersebut. Salah satu polimer yang memiliki jumlah gugus aktif yang melimpah adalah polidopamin. Polidopamin memiliki berbagai macam gugus aktif seperti gugus hidroksida, amina dan aromatis. Dengan keberadaan gugus aktif tersebut, diharapkan polidopamin dapat mengikat logam berat melalui interaksi elektrostatis, koordinasi, ikatan hydrogen, maupun interaksi phi-phi [5]

Berdasarkan penjelasan diatas, maka dilakukanlah pengembangan membran kitosan termodifikasi polidopamin untuk adsorpsi timbal dalam air.

\section{METODE PENELITIAN}

\section{Material}

Kitosan, polietilen glikol (PEG), $\mathrm{Pb}\left(\mathrm{NO}_{3}\right)_{2}$, glutaraldehid, asam asetat, Tris buffer $\mathrm{pH} 8.5$ dan ethanol dari WAKO Chemical, deionized water, milli-Q water dari, dopamine-hydrochloride dari TCI. Semua bahan yang digunakan adalah pure analysis grade.

\section{Instrumentasi}

Konsentrasi timbal sebelum dan sesudah adsorpsi diukur dengan menggunakan spektrometri serapan atom.

\section{Prosedur}

$\begin{aligned} & \text { Pembuatan membran kitosan dan } \\ & \text { kitosan/PEG }\end{aligned}$

Kitosan dilarutkan dalam 1\% asam asetat sehingga menghasilkan larutan kitosan (3.5 $\%$ w/v). Setelah itu, sebanyak 10\% glutaraldehid ditambahkan sebagai crosslinker. Larutan peg $(3.5 \% \mathrm{w} / \mathrm{v})$ dibuat dengan melarutkan peg ke dalam air. Membran kitosan dibuat dengan mencetak larutan kitosan dalam cawan petridish. Membran kitosan/peg dibuat melalui pencempuran antara larutan kitosan dan larutan peg dengan berbagai variasi jumlah peg. Campuran tersebut kemudian di aduk selama 24 jam untuk menghasilkan larutan yang homogen. Setelah itu, campuran dicetak dalam cawan petridish.

\section{Modifikasi Membran Kitosan dan Kitosan PEG}

Membran direndam dalam larutan $\mathrm{NaOH}$ selama 2 jam. Setelah itu, membran direndam dalam akuades, lalu dikeringkan. Membran yang sudah kering direndam dalam larutan polidopamin yang dibuat dengan melarutkan sejumlah polidopamin ke dalam $750 \mathrm{ml}$ larutan Tris-CL buffer $\mathrm{pH}$ 8,7. Proses perendaman disertai pengocokan dengan menggunakan orbital shaker selama 18 jam. Setelah itu, membran dicuci dan dikeringkan.

\section{Aktivitas Adsorpsi}

Kemampuan adsorpsi membran yang telah dibuat dalam mengikat timbal dalam air diukur dengan menggunakan metoda batch. Sebanyak $0.1 \mathrm{~g}$ membran direndam dalam botol yang mengandung $20 \mathrm{ml}$ larutan $\mathrm{Pb}\left(\mathrm{NO}_{3}\right)_{2} 50 \mathrm{ppm}$. Setelah itu, campuran dikocok dengan menggunakan orbital shaker selama 24 jam. Larutan timbal sebelum dan 
sesudah adsorpsi diukur dengan menggunakan spektroskopi serapan atom.

Jumlah timbal yang teradsorp dalam setiap membran dihitung dengan menggunakan persamaan berikut :

$$
q=\frac{(\mathrm{Co}-\mathrm{Ce}) \mathrm{V}}{\mathrm{M}}
$$

Sedangkan persen timbal yang teradsorb $(\mathrm{R} \%)$ dihitung dengan menggunakan persamaan berikut :

$$
\mathrm{R} \%=\frac{\mathrm{Co}-\mathrm{Ce}}{\mathrm{Co}} \times 100
$$

Co adalah konsentrasi awal $\left(\mathrm{mg} \mathrm{L}^{-1}\right)$, Ce adalah konsentrasi saat setimbang, $\mathrm{V}$ adalah volume larutan yang diuji and $M$ adalah massa adsorbent [6].

\section{HASIL DAN PEMBAHASAN}

Membran kitosan termodifikasi polidopamin dibuat dengan metoda lapis (coating). Membran direndam dalam larutan dopamin. Dopamine merupakan bentuk monomer dari polidopamin. Dopamine dapat dengan mudah teroksidasi pada $\mathrm{pH}$ basa menghasilkan 5,6-dihidroksindol (DHI) melalui oksidasi intramolekular. DHI kemudian terpolimerisasi secara sendirinya membentuk polidopamin yang akan menempel pada permukaan [7].

Terdapat perbedaan warna diantara membran dengan variasi konsentrasi polidopamin. Semakin tinggi konsentrasi polidopamin yang digunakan, yaitu 0,1 - 0,5 $\mathrm{kg} / \mathrm{L}$, maka semakin pekat warna yang dimiliki oleh membran tersebut hal ini menandakan semakin banyaknya polidopamin yang melapisi membran kitosan.
Studi adsorpsi membran yang telah dikembangkan terhadap ion $\mathrm{Pb}$ (II) dalam air dilakukan dalam media netral $(\mathrm{pH}$ 6) atau sama dengan $\mathrm{pH}$ akuades. Pada gambar 1 dibandingkan kapasitas adsorpsi membran kitosan (chi) dengan kitosan termodifikasi peg dengan berbagai persentase (chi + peg) dan membran kitosan/peg termodifikasi polidopamin (chi+peg+pda). Polidopamin yang digunakan dalam hal ini adalah $0.5 \mathrm{~kg} / \mathrm{L}$. Penambahan peg bertujuan untuk membentuk pori membran sebagaimana hasil penelitian Gupta dan Saxena [8]. Dari grafik tersebut, semakin besar penambahan peg pada kitosan semakin menurun kapasitas adsorpsi membran terhadap ion $\mathrm{Pb}(\mathrm{II})$. Membran kitosan saja menghasilkan \%R sebesar $36 \%$, sedangkan kitosan+10\% peg menghasilkan \%R sebesar 4\% dan kitosan + $20 \%$ peg sebesar $0 \%$. Penurunan ini dikarenakan semakin banyak peg yang ditambahkan, maka semakin banyak pori membran yang terbentuk sehingga semakin mudah membran tersebut larut dalam air.

Kemudahan membran larut dalam air membuat sebagian besar media air terserap ke dalam membran sehingga, konsentrasi ion $\mathrm{Pb}(\mathrm{II})$ setelah proses adsorpsi, seakan meningkat atau tetap sama. Setelah membran kitosan + peg di modifikasi dengan polidopamin, kapasitas adsorpsi untuk kitosan $+5 \%$ peg, kitosan $+10 \%$ peg, kitosan $+20 \%$ peg dan kitosan $+30 \%$ peg memiliki \%R secara berturut-turut sebesar $4 \%, 28 \%, 36 \%$, $36 \%$, dan $32 \%$. 


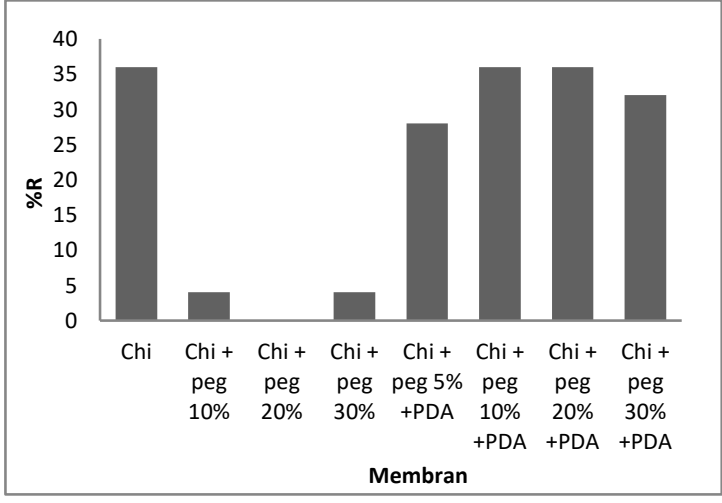

Gambar 1. Kapasitas adsorpsi membrane kitosan (Chi), kitosan/peg (Chi+peg) dan kitosan/peg/pda (Chi+peg+pda) terhadap ion $\mathrm{Pb}(\mathrm{II})$.

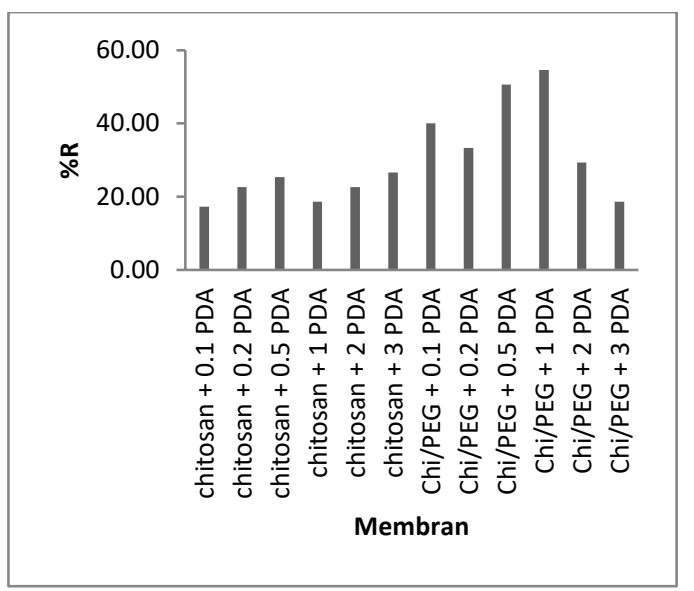

Gambar 2. Kapasitas adsorpsi membrane kitosan

(Chi), kitosan/peg (Chi+peg) dan kitosan/peg + pda dengan berbagai variasi konsentrasi

Pada gambar 1, \%R dari membran kitosan $+0,1 \mathrm{~kg} / \mathrm{L}$ pda, kitosan $+0,2 \mathrm{~kg} / \mathrm{L}$ pda, kitosan $+0,5 \mathrm{~kg} / \mathrm{L}$ pda, kitosan $+1 \mathrm{~kg} / \mathrm{L}$ pda, kitosan $+2 \mathrm{~kg} / \mathrm{L}$ pda dan kitosan +3 $\mathrm{kg} / \mathrm{L}$ pda secara berturut-turut sebesar $17 \%$, $22 \%, 25 \%, 19 \%, 22 \%, 26 \%$. Besarnya \%R untuk membran kitosan + peg $10 \%+0,1 \mathrm{~kg} / \mathrm{L}$ pda, kitosan + peg $10 \%+0,2 \mathrm{~kg} / \mathrm{L}$ pda, kitosan + peg $10 \%+0.5 \mathrm{~kg} / \mathrm{L}$ pda, kitosan + peg $10 \%+1 \mathrm{~kg} / \mathrm{L}$ pda, kitosan + peg $10 \%+2$ $\mathrm{kg} / \mathrm{L}$ pda, dan kitosan + peg $10 \%+3 \mathrm{~kg} / \mathrm{L}$ pda, secara berturut-turut sebesar $40 \%, 33 \%$, $50 \%, 54 \%$, 29\% dan $19 \%$.
Pengurangan \% $\mathrm{R}$ dari membran kitosan/peg/pda seiring dengan kenaikan konsentrasi pda dikarenakan adanya penutupan sebagian pori membran, sehingga interaksi antara adsorbat dengan adsorben menjadi tidak maksimal $[9,10]$.

\section{KESIMPULAN}

Pengembangan membran kitosan termodifikasi peg dan pda telah dilakukan. Hasil pengukuran kapasitas adsorbansi dari berbagai variasi membran tersebut terhadap ion $\mathrm{Pb}$ (II) dilakukan dengan menggunakan metoda batch. Hasil menunjukkan adanya ketidakstabilan dari membran yang ditandai oleh ketidak konsistenan dari banyaknya ion $\mathrm{Pb}$ (II) yang terserap. Kapasitas adsorpsi maksimum dicapai oleh membran kitosan + peg $10 \%$ + pda $1 \mathrm{~kg} / \mathrm{L}$ yaitu sebesar $54 \%$.

\section{DAFTAR PUSTAKA}

[1] S. Abdelkarim, H. Mohammed, and B. Nouredine, "Sorption of Methylene Blue Dye from Aqueous Solution Using an Agricultural Waste," Trends Green Chem., pp. 1-3,2017.

[2] G. Hong, L. Shen, M. Wang, Y. Yang, X. Wang, M. Zhu, and B. S. Hsiao, "Nanofibrous Polydopamine Complex Membranes for Adsorption of Lanthanum (III) Ions," Chemical Engineering Journal., volume(244), pp. 307-316, 2014.

[3] A. Ghaee, M. Shariaty-Niassar, and J. Barzin, A. F. Ismail, "Chitosan/Polyethersulfone Composite Nanofiltration Membrane for Industrial Wastewater Treatment," International Journal Nanoscience and Nanotechnology, volume(9), pp.213-220, 2013.

[4] N. Gupta, A.K. Kushwah, and M.C. Chattopadhyay, "Adsorptive removal of $\mathrm{Pb}^{2+}, \mathrm{Co}^{2+}$, and $\mathrm{Ni}^{2+}$ by hydroxyapatite/Chitosan Composite from Aqueous Solution," Journal of Taiwan Institute of Chemical Engineering, volume(43), pp.125-131, 2012.

[5] S. Zhang, Y. Zhang, G. Bi, J. Liu, Z. Wang, Q. Xu, H. $\mathrm{Xu}, \quad \mathrm{X} . \quad \mathrm{Li}, \quad$ "Mussel-inspired Polydopamine Biopolymer Decorated with Magnetic Naoparticles for Multiple Pollutants Removal," Journal of Hazardous Materials., volume(270), pp. 27-34, 2014.

[6] M. Aliabadi, M. Irani, J. Ismaeili, H. Piri, M. J. Parnian, "Elekrospun Nanofiber Membrane of PEO/Chitosan for the Adsorption of Nickel, Cadmium, Lead and Copper Ions from Aqueous Solution," Chemical Engineering Journal., volume(220), pp. 237-243, 2013. 
[7] Y. Li., Y. Su, J. Li, X. Zhao, R. Zhang, X. Fan, J. Zhu, Y. Ma, Y. Liu, and Z. Juang, "Preparation of Thin Film Composite Nanofiltration Membrane with Improved Structural stability Through the Mediation of Polydopamine," Journal of Membrane Science., volume(476), pp. 10-19, 2015.

[8] B. Gupta, S. Saxena, "Chitosan-Polyethilene Glycol Coated Cotton Membranes for Wound Dressing," Indian Journal of Fibre \& Textile Research., volume(36), pp. 272-280, 2011.

[9] J. Yang, Y. Huang, Y. Miao, W. W. Tjiu, and T. Liu, "Polydopamine-coated Electrospun Poly(vinyl alcohol)/Poly(acrylic acid) Membranes as Efficient Dye Adsorbent with Good Recyclability," Journal of Hazardous Material., volume(283), pp. 730-739, 2015.

[10] Chairunnisa, D. Siswanta, A. Suratman, S. Tanaka,"Shirasu Balloons and Polydopaminemodified Shirasu Balloons for Adsorption of Methylene Blue," Water Air Soil Pollution., volume(227), pp. 412-423, 2016. 